\title{
THE TAMAN SISWA IN POSTWAR INDONESIA
}

\author{
Lee Kam Hing
}

Taman Siswa, with its emphasis on a national education to unite the various cultural and ideological segments in Indonesia, has always been identified with the prewar nationalist movement. Established in 1922 by $\mathrm{Ki}$ Hadjar Dewantoro as the Nationaal Onderwijs Instituut "Taman Siswa," the movement was to some extent a reaction to the "deracinating" effects of Western education. ${ }^{1}$ In Taman Siswa schools, attention was given to the study of what was then beginning to be accepted by some nationalists as the national culture. In Java, where most of the Taman Siswa schools were located, Javanese music, plays, and classical dances were taught, while Western songs and related cultural activities were avoided. In the teaching of history, emphasis was placed on Indonesia's precolonial past. Vernacular languages were used as the media of instruction in the lower grades, while Malay and Dutch were taught only in the higher classes. English was included as a second or third language in the secondary schools. But above and beyond formal coursework, what Taman Siswa offered were educational opportunities to those aspiring to social mobility but who, because of low social standing, had encountered difficulties in gaining admittance to government schools.2 By the beginning of the Second World War, Taman Siswa had a total of 199 branches, with 207 schools, 650 teachers, and about 20,000 pupils.

Taman Siswa attracted the support of many who regarded the organization as working towards the political objectives of national unity and independence. Some associated themselves with Taman Siswa because they believed this affiliation gave them scope to contribute to the cause of nationalism, particularly at a time when the Dutch were taking tough repressive measures against overt political activities. Consequently, despite its leaders' frowning on politics in the schools, Taman Siswa tended to encourage the growth of anticolonial sentiments among its members. Such factors as the socioeconomic background of its pupils, the presence of radical nationalists on its teaching staff, Ki Hadjar Dewantoro's pedagogical approach, and its atmosphere of

${ }^{1} \mathrm{~A}$. Zainu'ddin, "Education in the Netherlands East Indies and the Republic of Indonesia," Melbourne Studies in Education (1970), pp. 30-35; B. J. Mulherin, "Ki Hadjar Dewantara: Indonesian Cultural Nationalist" (M.A. thesis, Queensland University, 1969); C. Penders, "Colonial Education Policy" (Ph.D. thesis, Australian National University, 1967); W. le Fèbre, Toman Siswa (Jakarta: Balai Buku Indonesia, 1952), pp. 12-20; Kenji Tsuchiya, "The Taman Siswa Movement--Its First Eight Years and Javanese Background," Journal of Southeast Asian History, 6, 2 (1975), pp. 164177; and R. Van Nie1, The Emergence of the Modern Indonesian Elite (The Hague: van Hoeve, 1960), pp. 220-22.

2Ruth T. McVey, "Taman Siswa and the Indonesian National Awakening," Indonesia, 4 (October 1967), p. 146. 
cultural nationalism--all contributed to a heightened political consciousness. By the time the 1932 Taman Siswa congress was held, there was already a large group of political activists within the organization, many of whom were also members of the Partai Indonesia (Partindo) and the Pendidikan Nasional Indonesia (residues of Sukarno's banned PNI) .

Following independence, however, Taman Siswa was no longer as important and purposeful an organization as it had once been. It seemed to have difficulty in adjusting to a postindependence situation where many of the initiatives in educational change now came from an Indonesian government. Amidst a rapid expansion of government schools and the infusion of nationalism into the general education system, Taman Siswa was unable to establish a new and meaningful role. Increasingly, it survived simply as an appendix of the state school system. At best, it served as the custodian of $\mathrm{Ki}$ Hadjar Dewantoro's teachings as well as a memorial of its own past role in the struggle for independence. In comparison with other private schools, the postwar growth of Taman Siswa was slow. It failed to attract exceptional students even of humble background. Only those children who were unable to get into or continue in the government system sought places in its schools.

In the postrevolutionary period, then, Taman Siswa existed almost entirely as an educational body and no longer represented broader objectives. Other important private educational organizations, such as Muhammadiyah, the Christian schools, the Chinese Baperki (Badan Permusjawaratan Kewarganegaraan Indonesia, Consultative Body for Indonesian Citizenship), the pro-PKI (Partai Komunis Indonesia, Indonesian Communist Party) Gerwani (Gerakan Wanita Indonesia, Indonesian Women's Movement), the Lembaga Pendidikan Nasional (National Education Institute), and even the Islamic madrasah or religious schools were attached to groups identified by religion, ideology, or race, and their schools met particular community needs. Taman Siswa, however, seemed to have lost a definable constituency.

Yet despite this obvious decline, in many respects the organization still had meaning in Indonesia after 1945. To many, it was a reminder of the country's heroic nationalist past. ${ }^{3}$ In the colonial period, it had developed and offered an education which many Indonesians could claim as designed for them as Indonesians. Consequently, Taman Siswa leaders continued to be highly regarded in the field of education as well as in politics. They were regularly invited to sit on the government's numerous committees or consultative bodies on education. Ki Hadjar Dewantoro was appointed Minister of Education in the very first Republican cabinet and was subsequently called on to advise the government on several occasions. ${ }^{4}$ Another Taman Siswa leader, Sarino Mangunpranoto, was Education Minister during the second Ali Sastroamidjojo cabinet. Some people who had been active Taman Siswa members in the prewar years were now drawn into the state schools and the educational bureaucracy, and a number of them assumed leader-

${ }^{3}$ In November 1959, Ki Hadjar Dewantoro was proclaimed a national hero, and a month later his birthday, May 2, was declared a national holiday.

4"Keterangan Ki Hadjar Dewantoro tentang kembalinja aktif didalam usaha Taman Siswa," Pusara, 14, 9-12 (January-March 1953), p. 187. 
ship in teachers' organizations. Moreover, simply as an educational organization, the Taman Siswa still had more than a hundred schools, including its own teachers' training colleges, and it therefore remained a significant private school system.5

The problem faced by the postwar Taman Siswa was that of adjusting itself to what was clearly a different political environment and of seeking a role in a new educational system. ${ }^{6}$ In the prewar era, it had rejected the Dutch government's educational system and had tried to have as little to do with the colonial authorities as possible. Despite perennial financial difficulties, Taman Siswa had always refused to seek assistance from Batavia, arguing that to do this would compromise its principles. This stand bore heavy costs, including inadequate school facilities and low pay for its teachers. Yet these hardships were bravely borne by most members of the organization, who regarded their economic difficulties as necessary sacrifices for the nationalist cause. But now that the government was in Indonesian hands, such sacrifices no longer had the same moral compeliingness.

The Role of the Taman Siswa in Postrevolutionary Education

One issue that soon led Taman Siswa to a reexamination of its position was that of government subsidies. There were members who proposed that the organization should take advantage of government offers of assistance. Facing constant financial difficulty, they saw no reason why such assistance should, if offered, be refused. Many Taman Siswa teachers could see little point in making monetary sacrifices under circumstances where no meaningful point was thereby being made. Furthermore, there were those who felt that the old oppositionist attitudes of Taman Siswa were irrelevant and that the organization should now cooperate closely with the Education Ministry.

There was, however, considerable resistance among the Taman Siswa leaders to any change of policy on the subsidy issue. They argued that the acceptance of assistance from the government would greatly reduce

5Taman Siswa: Ten Years Preceding and Following the Second World War

\begin{tabular}{ccc|ccc}
\hline Year & School & Pupils & Year & Schoo1 & Pupils \\
\hline 1932 & 166 & 11,000 & 1950 & 78 & - \\
1933 & 170 & 11,500 & 1951 & 76 & 39,122 \\
1934 & 172 & 11,169 & 1952 & 88 & 42,254 \\
1935 & 187 & 11,235 & 1953 & 96 & 43,360 \\
1936 & 184 & 9,015 & 1954 & 100 & 44,575 \\
1937 & 190 & 12,000 & 1955 & 122 & 44,674 \\
1938 & 196 & 14,627 & 1956 & 144 & 48,907 \\
1939 & 205 & 14,499 & 1957 & 152 & 46,898 \\
1940 & 204 & 13,500 & 1958 & 159 & 49,126 \\
1941 & 204 & 12,000 & 1959 & 164 & 49,395 \\
\hline
\end{tabular}

Source: "Laporan Umum Madjelis Luhur Dalam Rapat Besar ke-IX Persatuan Taman Siswa, Maret 1960" (Unpublished report, Jogjakarta, 1960), pp. 12-13.

Gaman Siswa 30 Tahun (Jogjakarta: Madjelis Luhur Taman Siswa, 1956), p. 270. 
the freedom of Taman Siswa to pursue its own objectives. Many leaders feared that by seeking too eagerly to adapt itself to the new environment Taman Siswa would evolve into just another part of the general school system and be unable to emphasize or carry out the original Taman Siswa ideas. Possibly another reason was that there was an element of pride among the older and more conservative leaders, who did not wish to be perceived as pleading for financial assistance. Nonetheless, at a meeting of the Majelis Luhur (Supreme Council) in August 1945 this conservative position was questioned and eventually modified. It was decided that the Taman Siswa would not actively seek assistance from the government but, if it were offered, it would be accepted. The 1947 Taman Siswa congress, which was attended by representatives from all the branches, called for further change. ${ }^{7}$ In place of the passive policy recommended earlier by the Majelis Luhur, the congress passed a resolution urging the Taman Siswa actively to ask for government financial support.8

Just before Dutch-Indonesian hostilities broke out in July 1947 , Taman Siswa applied for and received very modest subsidies from the Republican government for most of its schools. With the outbreak of fighting, payments were disrupted but they resumed soon after the hostilities ended. At the request of the Taman Siswa, the new government then provided assistance in the form of loans and other subsidies to rehabilitate many of the schools which were in disrepair. ${ }^{9}$

As the country moved into a period of comparative stability and recovery, the Education Ministry began to reexamine its earlier haphazard allocation of aid to private institutions. While accepting the position that the government had the responsibility of assisting private education, the Ministry wanted tighter control and the introduction of more stringent conditions for future awards of subsidies. In 1954, the government publicly released its guidelines and stipulations. The Education Ministry ruled that only those private schools which met these requirements would receive assistance.

The new policy was disturbing to the Majelis Luhur, and it strengthened the position of those conservative members who all along had voiced their misgivings on the subsidy issue. The Majelis Luhur as a whole opposed the government's view that aid should be conditional upon fulfilling certain stipulations. It argued that the Education Law of 1950 had assured every child an education, and that the government was therefore obliged to extend assistance to children in all schools, regardless of whether they were state or private institutions. It would be unfair for the government to discriminate in favor of its own schools. On the principle of education for all, students in Taman Siswa schools were actually entitzed to subsidies, especially since the government itself was unable to provide sufficient schools for all. Perhaps most disturbing of all to the Majelis Luhur were the actual conditions out-

7"Usul-usul tjabang tentang Pendidikan," Pusara, 18 (April-August 1956), pp. 59-77.

${ }^{8}$ Toman Siswa 30 Tahun, pp. 270-74; and "Taman Siswa dapat tundjangan Rp. 2,500,000," Pewarta P.P.K., 4-5 (1956), p. 531.

9"Tentang Subsidi," Pusara, 1 (May 1950), pp. 13-14; and "Putusan Rapat Besar Umum Taman Siswa, Maret 1950 di Jogjakarta" (Unpublished report, Jogjakarta, 1950), pp. 6-8, 14-17. 
lined by the government, for these were seen as adversely affecting the independence of private educational organizations. The Majelis claimed that Taman Siswa was not opposed, for instance, to accepting government supervision, one of the conditions for receiving a subsidy. In fact it welcomed the government's ideas in this regard as possibly beneficial. Yet it also expressed its fear that the regulations might be interpreted or used by officials in a manner that would adversely affect Taman Siswa's development. ${ }^{10}$

It is apparent that the Taman Siswa leaders believed that because of the organization's historic role and the ideals for which it stood, it merited special recognition from the government in the form of exemption from the Education Ministry's subsidy conditions. ${ }^{11}$ Acceptance of the regulations would mean an abdication of its special status.

Nonetheless, Taman Siswa failed to persuade the Education Ministry to adopt a more accommodating policy. Relations between Taman Siswa leaders and Ministry officials remained distinctly cool. One significant factor that may help explain the poor relationship was the Taman Siswa ideal of dedication and sacrifice. Many Taman Siswa members held that even after independence such qualities were important, and they criticized the lack of education among teachers and officials of the Education Ministry. These feelings were best expressed by Mohd. Tauchid, one of the Taman Siswa leaders, in an article in Pusara, where he discussed the position of the Taman Siswa on teachers' unions. The article was written in response to queries from members who wanted to know if they ought to join such unions. Tauchid sharply distinguished the Taman Siswa from the rest of society. He described the organization as a family in which there were no class distinctions nor differentiated levels of authority. This being the case, trade unionism as such was not necessary in Taman Siswa. Outside of Taman Siswa, however, the ideals of a classless society had not been attained. Accordingly, unions were needed in the struggle for a just return to the workers. On this principle, the Taman Siswa supported unionism.

The Persatuan Guru Republik Indonesia [PGRI] is a union of teachers whose responsibility is to educate children, a responsibility which we share. However, we do not place much importance on the question of fighting for improved salaries, because the Taman Siswa community is different from the world of labor. The PGRI is fighting for a society which we already have. But we must assist them. There is no need to demand an improved salary here since we pay ourselves. ${ }^{12}$

But even so, support for the PGRI, the principal teachers' union in Indonesia, was not unqualified. Tauchid explained that teaching was unlike other professions. Where industrial unions could use the strike as an instrument to achieve their demands, it was questionable whether teachers should employ similar tactics, as the ultimate victims of any such disputes would be their students. The teachers' first responsibility was the children.

10"Laporan Umum Madjelis Luhur," p. 115.

11"Subsidi/bantuan Pemerintah," Pusara, 18 (April-August 1956), pp. 53-58. p. 8 .

12Mohd. Tauchid, "Taman Siswa dan Perdjuangan Buruh," Pusara, 1 (May 1950), 
Accordingly, although Taman Siswa did not rule against its members joining labor organizations, members of the Majelis Luhur, including Tauchid, privately clung to the idealistic view, carried over from the prewar period, that teachers should be prepared to make sacrifices, even at the cost of having to lead a spartan life. Taman Siswa leaders did concede that teachers needed realistic wages to provide the basic necessities of life. But they maintained that it was the responsibility of the community and of the government to ensure that the needs of the teachers be met. Taman Siswa was critical of the fact that teachers and administrators in the state schools and in the Education Ministry increasingly seemed to view teaching simply as a profession and a career, thereby losing sight of what it believed to be the essential moral qualities required of educators.

To some extent, the factor of professionalism had another important effect on the position of the Taman Siswa vis-a-vis the Education Ministry. It served to emphasize the separation of two groups of prewar educators--Taman Siswa and non-Taman Siswa. The members of the latter group, who had been trained by the Dutch and were part of the colonial educational system, were, with independence, absorbed into the new state education system. Their skills were regarded as relevant to prevailing needs, and it was they who were called upon to function as educational administrators and technocrats to he1p formulate national educational programs. Meanwhile, the Taman Siswa group, which had been an integral part of the nationalist movement and which had helped to pioneer national education, now discovered that its ideas were deemed unimportant in the new language of postwar education. With this trend, Taman Siswa leaders gradually found themselves isolated from the state educational system in much the same way, although for different reasons, as they had been separated from the colonial educational system in the past. This isolation was all the more galling in that Taman Siswa leaders fe1t strongly that the organization had a worthwhile educational experience of its own to offer, formed during the struggle against the Dutch. In addition they had developed out of Dewantoro's teachings what they claimed was a coherent and distinct body of educational ideas. ${ }^{13}$

If it viewed the Education Ministry and its teachers as being too professiona1, Taman Siswa was in turn criticized for its lack of professionalism. Ministry officials believed that the organization did not measure up to the standards and requirements of modern state education institutions. Taman Siswa teachers were judged to be ill-qualified, standards in their schools were not studiously maintained, and equipment was invariably lacking. Most officials also felt that the organization had outlived its role and usefulness. In general, they argued that Taman Siswa was no different from any other private organization and that, like its competitors, it should be subjected to the guidelines prepared by the Ministry. As they saw it, the nation was faced with immense and complex educational problems to which the ideas that Taman Siswa had developed some twenty-odd years previously could only marginally contribute. For these officials, it was to be from the government and the Education Ministry, where many of the technocratic

13"Prasaran tentang hubungan Taman Siswa dengan dunia luar," Pusara, 18 (AprilAugust 1956), pp. 45-50. 
skills lay, that a11 initiatives for change in the field of education should come. ${ }^{14}$

Given the fact that it was no longer a symbol of national aspirations and that no special attention was accorded to it by the Education Ministry, Taman Siswa had to compete with other educational institutions both for students and for influence in the field of education. In both respects it invariably lost out. Most people regarded its ideas as irrelevant; and as an organization it no longer served as an asylum for political activists or the discontented. Taman Siswa was now judged solely by the ability with which it was able to function within the new system, not by the ideals it represented. One reflection of the declining influence of Taman Siswa was the level of motivation among its teachers. In the prewar period, many of the people who assisted in the Taman Siswa schools were deeply committed to ideas such as national independence and national identity and sought to achieve these through participation in the schools. After the war, few possessed such aspirations any longer. To the new teachers, teaching in the Taman Siswa was a job no different from any other. The type of students who now attended Taman Siswa also gave cause for dismay. Taman Siswa leaders increasingly realized that their organization was simply taking in dropouts from other schools or students who generally had not performed well. Parents sent their children to Taman Siswa schools only after they failed to be accepted elsewhere. In its report to the 1960 congress, the Majelis Luhur acknowledged: "Many people who send their children to Taman Siswa schools do not do so because they share the Taman Siswa ideas and beliefs. We can see this fact in the observation that our students in the Taman Dewasa or the Taman Madya and Taman Guru are in fact those who do not have a place in the state schools."15

The Majelis Luhur correctly perceived the reasons for this trend. By comparison to its own schools, the state and Christian private schools had better examination results, and parents concerned about the diplomas and certificates required for the career prospects of their children naturally chose these schools. The Majelis Luhur, however, was critical of this attitude. It commented that "although our society has gone through a revolution, yet clearly its attitude with regard to the problem of education has not changed much from the colonial period. Society continues to value education that is intellectua1."16 The attack on intellectualism here was really a reference to the preoccupation with selective study directed towards examinations, to the neglect of what Taman Siswa leaders thought was a more complete education in which the inculcation of vocational skills and the appreciation of the arts and culture were among the most important features. ${ }^{17}$

But merely deploring society's attitude was not an adequate answer to the crisis. Even those who did send their children to Taman Siswa, mainly people from the lower-middle and the working classes, attached

${ }^{14}$ Interview with Soegarda Poerbakawatja, head of the Jawatan Pengajaran Umum (1949-57), Jakarta, Apri1 23, 1971.

15"Laporan Umum Madjelis Luhur," p. 25. $\quad{ }^{16} \mathrm{Ibid} .$, p. 15.

17Speech of Wardojo at the opening of the Taman Siswa conference, 1969, in Taman Siswa dan Pembahaman Pendidikan (Jogjakarta: Majelis Luhur Taman Siswa, 1969), p. 6. 
great importance to schooling as a means toward a better job. Inevitably, then, Taman Siswa had to make adjustments in its thinking and organization in order to survive. In fact, in an early response to this need, many members of the Majelis Luhur had, in the months immediately after the war, advocated changes in the Taman Siswa curriculum to bring it closer to that of the state schools. Demands and pressures for curriculum revision had come particularly from branches in areas where the establishment of state schools had undermined whatever influence Taman Siswa schools once had. The right changes, Majelis Luhur leaders believed, would enable Taman Siswa students to sit for state examinations--and therefore not miss out on opportunities for higher education or jobs--and yet the essential Taman Siswa values could still be preserved.

The matter of school curriculum was the main subject of discussion at the Seventh Congress of the Taman Siswa in 1952. As on the subsidy is sue, calls for curriculum change encountered resistance from the older members, who feared that any revision would endanger all that the Taman Siswa had stood for. Eventually, a compromise was reached which significantly changed the orientation of the Taman Siswa schools. The compromise arrangement was described as the konkordansi (concordance) and the konpergensi (convergence) formulae. ${ }^{18}$ Under this arrangement, the primary and secondary schools of the Taman Siswa system--the Taman Indira, the Taman Muda, and the Taman Dewasa--which formed the great majority of its schools and which had to compete with the state schools for students, would follow the curriculum set by the Education Ministry. Each level and grade of the Taman Siswa schools would be patterned according to those of the state schools. This was the "concordance" part of the proposal. The change meant that students in Taman Siswa schools could prepare for state examinations and have similar opportunities for higher education or improved job prospects as students from state schools. Students could leave Taman siswa at any point to attend other types of schools, and vice versa, without difficulties or serious disruptions. In line with the "concordance" idea, Taman Siswa began accepting appointment of teachers from the government as part of the Education Ministry's assistance program.

According to the concept of konpergensi, however, the teachertraining Taman Guru, from which the main body of Taman Siswa teachers was drawn, was to remain a separate entity. This separation would allow Taman Siswa the opportunity to place more stress on its ideas when teaching student-teachers, while still retaining the essence of a state curriculum. ${ }^{19}$

Contrary to expectations, however, these changes did not improve the standing of Taman Siswa schools. Now that Taman Siswa was participating in the state examinations, its students' abilities could easily be compared with those of other schools. In general, they did not fare very well, owing to inadequate facilities, a lack of properly trained teachers, and the continuing reality that a large number of its students were either rejects or dropouts from elsewhere. The

18"Konpergensi dan konkordansi," Pusara, 18 (April-August 1956), p. 44; and K. H. Dewantoro, "Konkordansi dan konvergensi," Pusara, 14 (January-March, 1953), pp. 189,192 .

19 "Laporan Umum Madjelis Luhur," p. 25. 
appointment of government teachers did not noticeably improve the situation.

One of the reasons why there had been so much resistance to change in Taman Siswa was undoubtedly the dominance in the Majelis Luhur of that generation of leaders who had been with the organization almost from the start. By far the most important of these was Ki Hadjar Dewantoro, who despite ill health remained Taman Siswa's top leader until his death in 1959 .

During the early 1950s, however, two noticeably different attitudes emerged among the Taman Siswa leaders. One group favored total disinvolvement, especially in relation to the state education system. It wanted neither interference from the Education Ministry nor financial assistance, which it feared would undermine the organization's identity. This group preferred that Taman Siswa exist as an independent body and pursue its own ideals in relative isolation. Taman Siswa should quietly work to persuade the rest of society to accept its concept of national education. One can perhaps see here hints of a yearning for a monastic or pesantrèn type of separateness. ${ }^{20}$ The second group in the Majelis Luhur, accepting the fact that Indonesian society had moved significantly away from its prewar condition, was generally more responsive to calls for change. They believed that the expertise and the experience of Taman Siswa's members could and should be utilized by the Education Ministry in developing national education policies if the appropriate adaptations were made. ${ }^{21}$

Those who adopted this second view, such as Mohd. Tauchid and Sarino Mangunpranoto, were men who had been deeply involved in activities outside of Taman Siswa. Many of them had participated in prewar politics and continued to be associated with various political parties in the postrevolutionary period. Tauchid, for example, was a member of the ruling council of the Partai Sosialis (PS, Socialist Party) in its early years and later was active in the PSI (Indonesian Socialist Party). In October 1945, he had been elected head of the Barisan Tani Indonesia's (Indonesian Peasant League) information section. Beginning in 1947, he had served as a member of the revolutionary parliament, the KNIP (Komité Nasiona1 Indonesia Pusat, the Central Indonesian National Committee), and later represented the Republic in the larger federal parliament. Yet throughout this period he was also actively involved in Taman Siswa; indeed since 1938 he had been a member of the Majelis Luhur.22 Sarino Mangunpranoto, on the other hand, belonged to the Partai Nasional Indonesia (PNI, Indonesian Nationalist Party) and served as a cabinet minister in the second Ali Sastroamidjojo government. Mohd. Tachir Huseini, Imam Soekemi, Suratman, and Suprata all were said to have been closely associated with either the PSI or the PNI.

By contrast, members of the Majelis Luhur who favored a more isolationist position had generally dissociated themselves from political activities. Both Soedarminta, the chairman of Taman Siswa, and 1971 .

${ }^{20}$ Interview with Mohd. Said, head of the Jakarta Taman Siswa, Jakarta, June 1 ,

${ }^{21}$ Interview with Mohd. Tauchid, member of Taman Siswa's Majelis Luhur and currently its chairman, Jogjakarta, August 14, 1971.

220rang Indonesia Jang Terkemoeka di Djowa (Jakarta: Gunseikanbu, 1944), p. 412. 
Sajoga belonged to this group.23 Mohd. Said, although called upon later to serve on various government committees, sought to avoid entanglements with political parties and tended to identify himself with the Soedarminta, or murni group, as they were sometimes called. The term murni, meaning "pure," was used to describe their concern for keeping themselves and the organization uninvolved in party politics, an issue which by this time had become a point of contention within Taman Siswa.24

Many of the gradual changes in the organization after the revolution were really the result of demands from younger and more radical members. While the Tauchid group had been sympathetic to change, many of the initiatives and much of the pressure had come from the branches. Many leaders outside Taman Siswa's spiritual home, Jogjakarta, had watched with growing dismay what they felt was the gradual isolation and decline of the organization in the new Indonesian society and were deeply concerned that Taman Siswa was becoming irrelevant. Though the Tauchid group, by comparison to the murni group, was prepared to make some changes, the younger and more radical members felt that the changes were not sufficient to arrest the erosion of Taman Siswa's position.

That the questioning of Taman Siswa's role often came from its regional branches was certainly due in part to their geographical distance from the pervasive and often stifling influence of the Majelis Luhur in Jogjakarta. But the main factor was the extremely rapid postrevolutionary expansion of state schools into areas where Taman Siswa had once had little competition. Younger Taman Siswa members quickly recognized that good students would continue to be drawn away unless Taman Siswa offered an education of competitive quality. Furthermore, many in the younger group had frequent content with non-Taman Siswa groups and were therefore exposed to a wider range of ideas and challenges than were their elders. These groups included teachers seconded to Taman Siswa by the Education Ministry. These seconded teachers were invariably less familiar with and certainly less committed to Taman Siswa ideals than their colleagues. They brought with them experiences from their previous training and no doubt encouraged a more critical attitude towards conditions in Taman Siswa schools and the conservatism of the Majelis Luhur.

Another factor that added to the expression of dissatisfaction was the increasing politicization of the Taman Siswa organization itself. In the elections of 1955 and 1957, various organizations, including Taman Siswa, found themselves the foci of intense competition among political parties anxious to gain their support. Although regarded as an institution of diminishing influence, Taman Siswa nonetheless received considerably attention from these parties. The affiliation of Taman Siswa members with political parties was, as noted earlier, not new; many had been politically active in the past. Taman Siswa itself had no rule against members participating in politics, although as an organization it sought to stay neutral in all matters

230thers who probably belonged to this group were Suwandi, Pronowidigdo, Wonobojo, Tjokrodirdjo, and Puger. Suwandi and Pronowidigdo had been in the Majelis Luhur since 1934.

${ }^{24}$ Interview with Drs. Abdulrachman Surjomihardjo, member of Taman Siswa and presently a lecturer in history at the University of Indonesia, Jakarta, April 8, 1971 . 
that had overtones of political or religious controversy.25 In the prewar years, Taman Siswa felt itself in congruence with the broad political aims of the existing parties, all of which were working for the country's independence. But in the postwar period, party politics increased dissent within the organization. Many members who were ideologically committed to change in the wider society recognized that they would be inconsistent if they did not demand reforms of Taman Siswa as wel1.26 (In all of these growing internal conflicts, personal pettiness and rivalries were not unimportant.)

Taman Siswa and the PKI

The party that made the most impressive inroads into Taman Siswa was the PKI. That the Taman Siswa should have produced pro-PKI educators and supporters is not surprising, given the fact that the organization had always had a nonpartisan and accommodating approach to all political ideologies. In the prewar period, many radical nationalists were associated with Taman Siswa, and at one point allegations were made by the Dutch that several Taman Siswa branches were controlled by PKI partisans. In the postwar years, several PKI leaders, the most prominent of whom was Wikana, were Taman Siswa products. As a result, the PKI had found it relatively easy to gain early support in Taman Siswa. As early as the mid-fifties, there were reports that several branches in Central and East Java were dominated by pro-PKI members. Pro-PKI members were also said to have gained significant influence in the Persatuan Pemuda Taman Siswa (PPTS, Taman Siswa Youth Organization) and the Taman Guru.27

The PKI's relative success can be explained by several other factors as we11. Perhaps the most important was the apparent affinities between the party's ideology and the Taman Siswa world view. Even some of the language and imagery used by the PKI were very close to those of Taman Siswa. Taman Siswa referred to itself as a community with no hierarchy and no social classes. All were equal in the organization, which was viewed as a sort of family or kezuarga. ${ }^{28}$ Taman Siswa spoke out against exploitation of one group by another and

25Pusara, 17 (May 1955), p. 48; "Prasaran tentang hubungan Taman Siswa," p. 50.

${ }^{26}$ From interviews with Drs. Abdulrachman Surjomihardjo, Mohd. Said, and Mohd. Tauchid.

27"'Laporan Madjelis Luhur Taman Siswa Untuk Kongress ke-sepuluh Persatuan Taman Siswa, 5-10 Desember 1966 di Jogjakarta" (Unpublished report, Jogjakarta), pp. 1-8.

28"It is on this principle of kekeluargaan that a society must be built if it seeks to be harmonious, orderly, and peaceful, free from unjust discrimination based on class, color, or race and free from exploitation of man by man. . . That's why Taman Siswa is organized in such a way that there is no relationship of employeremployee in the capitalistic sense, and neither in the social status between teachers teaching in secondary schools and those teaching in primary schools, nor among those doing intellectual, administrative, or manual work. To Taman Siswa every kind of work is dignified as far as it is humane or not violating universal moral standards." Mohd. Said, Taman Siswa: Its Principles and Practice (Jogjakarta: Majelis Luhur Taman Siswa, 1972), pp. 16-17. 
frowned on the acquisition of excessive wealth for its own sake. Some Taman Siswa members believed in building a community in which no member would suffer privations and where earnings would be shared. Frugality was generally encouraged, and a spirit of sacrifice and service demanded. Moreover, as an organization that had grown from the nationalist movement, Taman Siswa's image was consistent with that of the PKI on issues of anticolonialism and anti-imperialism.

It should not be forgotten that the Taman Siswa members belonged, culturally and socially, to the community to which the PKI most appealed.29 Culturally, Taman Siswa had always been a predominantly Javanese organization and its members adhered mainly to what Geertz has called the priyayi-abangan tradition. Most of Taman Siswa's branches were in Central and East Java, with the main concentration in the Jogjakarta region. In class terms, the majority of Taman Siswa members were lower-middle or lower class. Most of the students, too, were drawn from poorer income groups.

It has been suggested that the growing influence of the PKI in Taman Siswa developed from the large number of teachers seconded to it by the Education Ministry during the 1950s. It was 1 ater claimed that many of these teachers were members or sympathizers of the PKI and that their appointment was part of a deliberate plan by the Ministry to strengthen communism in Taman Siswa. Such a scheme, it was alleged, was made with the knowledge of the Education Minister, Prijono, who was regarded as sympathetic to the PKI.30 This seems unlikely. While the presence of a large number of non-Taman Siswa teachers undoubtedly exposed the organization to outside influences, communism was certainly only one of these. Furthermore, it would not be surprising in any case if a significant proportion of the appointed teachers were PKI sympathizers, since by this time the communist party had successfully attracted many teachers to its ranks, especially those with low status and salaries. In fact, the fifties saw active interest in the Taman Siswa from other groups as well; other parties, especially the PNI, were just as deeply involved.

Party activities and increased political factionalism within Taman Siswa were in large part due to the 1955 general elections, which encouraged the parties to try to build up support in various organizations and institutions. In the 1955 general elections, and 1 ater in the 1957 local elections, the PKI polled very well in Central and East Java. Indeed in the 1957 elections, the PKI obtained even more votes in Central Java than the PNI, which had expected to win the major share of seats. Thus the PKI's growing influence in the Taman Siswa branches of Central and East Java should basically be understood in the context of its impressive electoral gains.

Leaders of the pro-PKI group in Taman Siswa tended to be younger and better educated. Many of them had studied at Gajah Mada University and the Institut Keguruan Ilmu Pengetahuan and were strongly influenced by a few of the strongly pro-PKI lecturers there. They saw themselves as the best qualified segment of the Taman Siswa leadership and were

${ }^{29}$ Rex Mortimer, "Class, Social Cleavage and Indonesian Communism," Indonesia, 8 (October 1969), pp. 1, 20.

${ }^{30}$ Interview with Mohd. Tauchid, Jogjakarta, August 14, 1971. 
therefore impatient with the older generation of Dutch-educated but nonuniversity members in the Majelis Luhur.

Many of these younger members began to look beyond the Taman Siswa for channels to express their views, while others were determined to work for change within the organization. Those who decided to work outside of the Taman Siswa soon established contact with pro-PKI bodies, such as the Lembaga Pendidikan Nasional (National Education Institute), the Himpunan Sarjana Indonesia (Association of Indonesian Scholars), and the Universitas Rakyat (People's University). The choice for some was primarily ideological. For others, it was simply that these organizations happened to be expanding their activities and therefore offered welcome opportunities. Still others moved into nonpolitical and strictly profit-motivated educational institutions. Undoubtedly, in all cases there was a quest for personal advancement and an expectation that working in Jakarta could lead to immediate gain and possibly to participation in the political process.

There were, however, many pro-PKI members who remained inside Taman Siswa in Jogjakarta. They proved very successful in influencing the PPTS, the Taman Guru, and several branches. Both the Jakarta and the Jogjakarta groups apparently worked closely together. Even though the Jakarta group busied itself with educational issues in the capital, it continued to be attentive to what was happening in Taman Siswa's "home." It is possible that those in Jakarta acted as a link between the Jogjakarta radicals and PKI educational bodies in the capital; they also served both within and outside Taman Siswa as the articulators of new educational ideas that proved attractive to the younger and more restless members.

Given the political atmosphere of the late fifties, it could also be said that many of those Taman Siswa members who were drawn to the pro-PKI faction were people excited by Sukarno's ideas on Guided Democracy. They were attracted to his theme of "the unfinished revolution" and his stress on "national greatness," and as much as anyone else they gave enthusiastic support to his campaign to recover West Irian from the Dutch. In their fervor, they backed the moves of the radical faction to mobilize Taman Siswa behind the President and his programs, and they identified the changes they wanted in Taman Siswa with immediate national goals.

In many ways, the pro-PKI faction came to represent the desire of those members, especially those in the PPTS and the Taman Guru, who believed that the Taman Siswa ought to work more closely with the Education Ministry than was then the case. Part of this feeling was guided by their view that while the ideas of Education Minister Prijono were in accordance with those of Dewantoro, as well as being relevant to the country's needs, Taman Siswa under its existing leadership was no longer the revolutionary organization it once had been. They believed that it was increasingly anachronistic because it was led by old and conservative leaders who seemed more anxious to live on the glories of the past than take on the challenges of a changing society.

In seeking to draw Taman Siswa into Prijono's education program, pro-PKI members called for the implementation of Sukarno's political doctrines of Manipol-Usdek. In an article published in December 1960 , entit1ed "Taman Siswa and the Political Manifesto," the pro-PKI group 
argued that Manipol was consistent with Taman Siswa principles.31 Quoting at length from Dewantoro's book Demokrasi dan Leiderschap, the article maintained that Taman Siswa had long fought for the objectives which Manipol had now formalized. It further argued that the concepts of Guided Democracy and Guided Economy, the core ideas of Manipol, were fully consistent with the ideals of Taman Siswa.

Proposals were subsequently made to the Majelis Luhur by the proPKI group that positive steps be taken to implement Manipol-Usdek in Taman Siswa schools. Indoctrination courses should be established for the teachers to ensure a proper appreciation of Sukarno's ideas. Such political courses ought to be given both at Jogjakarta and at the branches; if sufficient expertise was not available within Taman Siswa's own ranks, outsiders should be called in. While they did not say so openly, the pro-PKI group probably meant by "outsiders" the formulators of Panca Wardhana ${ }^{32}$ and the PKI-sponsored Panca Cinta. ${ }^{33}$ They also called for revision of the Taman Siswa curriculum, proposed including Manipol-Usdek and Panca Sila as subjects of instruction, and urged adoption of the Education Ministry's Sapta Usaha Tama ${ }^{34}$ as a general guide for school activities. ${ }^{35}$ The implications of these suggestions were not lost upon the Tauchid group, who saw them as further moves to "infiltrate" Taman Siswa.

The enthusiastic response of the younger Taman Siswa members to Sukarno's Guided Democracy was by no means shared by their elders. The murni group, in general, was anxious to keep the organization out of any politics at all. The others, however, and especially Mohd. Tauchid, accepted the fact that the Majelis Luhur must be prepared to accommodate the new symbols and vocabulary emanating from the Education Ministry. Such accommodation would at least be a way of neutralizing excessive pressure and interference from the groups supporting Prijono. The Tauchid group were not always comfortable with the new political language, but, so long as Taman Siswa remained independent, they would still be relative1y free to interpret this language in their own way. Pro-PKI members, on the other hand, recognized that by associating Taman Siswa with Prijono's Education Ministry and with pro-PKI educational organizations, the process of radicalizing Taman Siswa would be greatly facilitated. Changes within the Taman Siswa could be accomplished more easily once an initial formal acceptance of some outside influence had been achieved.

31"Taman Siswa dan Manipol-Usdek, 17 Desember 1960," in "Laporan Madjelis Luhur Harian 1960-1964 untuk Rapat Madjelis Luhur ke-III tanggal 16-21, Mei 1961" (Unpublished report, Jogjakarta).

32Panca Wardhana consisted of the five principles of education upon which Guided Democracy education was proposed to be based.

${ }^{33}$ Panca Cinta (Five Loves) was always identified as a set of precepts proposed by the PKI to be inculcated in the schools.

${ }^{34}$ Sapta Usaha Tama (Seven Chief Endeavors) was introduced by Prijono in August 1959 partly to demonstrate that changes in education were underway with the return of the country to presidential rule. It consisted of seven areas of activities to be carried out in all schools, with the aim of reviving national awareness and patriotism.

35"Sidang ke-II, 20 Februari 1962," in "Notulen Rapat Madjelis Luhur ke-IV, tg1. 19-24 February 1961 di Kaliurang-Jogjakarta" (Unpublished report, Jogjakarta), pp. $16-18$. 
The 1956 congress of the Taman Siswa revealed the strength of the PKI in the organization. Of the fourteen members elected to the new Majelis Luhur, six were men closely identified with the radicals.36 This was an impressive gain, since in the past the Majelis Luhur had been totally dominated by noncommunists. Of the six members known to be close to the PKI, three held important posts in the six-man Majelis Harian, Taman Siswa's day-to-day governing body. The deputy chairmanship and the posts dealing with organizational affairs and welfare went to pro-PKI members. Of these, the post in charge of organization was perhaps the most important, since the Majelis Luhur's communication with the branches and the arrangement of congresses and meetings were entrusted to it. It was later claimed by the noncommunists that it was through control of this position that the pro-PKI group extended its influence to the branches. It was alleged, for instance, that many known anticommunist branches were not informed of the election to fill the seat left vacant by the death of Soedarminta, and as a result a pro-PKI member was elected. ${ }^{37}$ The pro-PKI faction in the Majelis Luhur also dominated Pusara, Taman Siswa's main publication. After 1959 , five of the eight editorial board members belonged to the proPKI faction. ${ }^{38}$ Most of the pro-PKI group in the Majelis Luhur and in positions of branch leadership had been in Taman Siswa for a long time and were well known within the organization. It is said that a number of them were close to $\mathrm{Ki}$ Hadjar Dewantoro. Some had proved to be among the most diligent and capable of the organization's members. Accordingly, the pro-PKI faction attracted a strong following.

The noncommunists in the Majelis Luhur were worried by these trends, and especially by the outcome of the 1956 congress. Some, such as Mohd. Tauchid, warned that the growing influence of the PKI was a well-thought-out plan aimed at taking over the organization. They suggested that branches dominated by the pro-PKI group were given strict instructions on how to vote at the 1956 congress and that 1 ists of pro-PKI candidates were provided. As a result, the procommunists, voting as a block, gained a much larger proportion of seats in the Majelis Luhur than their actual membership strength warranted.

The fears of the noncommunists gained apparent confirmation in November 1958, when documents alleged to detail PKI intentions in Taman Siswa were said to have been intercepted. The documents and details of the PKI "plan" were submitted anonymously to Tachir Husseini, chairman of the East Java Taman Siswa, by the interceptor. Tachir immediately contacted other members of the Majelis Luhur known to be opposed to the communists. The anonymous letter stated that twenty of the forty-two Taman Siswa branches in East Java had already come under the control of PKI sympathizers. ${ }^{39}$ A list of those branches was given. It described the infiltration in East Java as being coordinated by Taman Siswa leaders in Jogjakarta with supposed PKI links, and warned that activities in that province were aimed at securing domination by the left-wing faction.

36"Laporan Umum Madjelis Luhur," p. 16.

37Interview with Mohd. Tauchid, Jogjakarta, August 11, 1971.

38pusara, 21 (September 1959), p. 1.

${ }^{39}$ Cited in "Rapat Panitia XI, 13 Nopember 1962," in "Notulen Rapat Madjelis Luhur ke-V pada tg1. 8-20 Nopember 1962 di Kaliurang-Jogjakarta" (Unpublished report, Jogjakarta), pp. $72-73$. 
Included in the intercepted papers was a document which was described as a report of the PKI's subsection committee in Taman Siswa. (It is significant that this document's authenticity was never denied by the radical faction.) According to the document, the subsection was formed in August 1957 with about forty-six members. By the time the report was made this number had increased to ninety-six, with most of the new support coming from the Taman Guru, the Ibu Pawiyatan (Women's Organization) at Jogjakarta, and the branch at Gading (in Jogjakarta). All three were branches important to any group seeking to gain eventual control of the organization. The document also referred to a closed meeting during the fourth plenum of the PKI Central Committee, which was devoted entirely to the question of the party's position with regard to Taman Siswa. The report of the communist subsection committee in Taman Siswa read in part:

In our report of the general situation [in Taman Siswa] we will not forget to explain the connection between Taman Siswa and the PKI. This matter has been decided in the plenum of the Central Committee. There the main outline has been drawn up so that this educational institution could truly become a base for the PKI or a base for intellectual cadres. As a result, our comrades have the task of informing the Party regarding this national educational institution. The Party recognizes that this national education institution is anticolonial and revolutionary. ${ }^{40}$

Upon receiving the documents the noncommunists immediately assembled, but could not agree on a strategy to meet the threat. The Tauchid group would probably have liked to take some action, but were restrained by several factors. The first of these was the prestigious presence of Dewantoro and the murni group. Dewantoro, it appears, was not convinced that there was a PKI plot to take over Taman Siswa. The pro-PKI members were men with whom he was closely acquainted, and their actions had not seemed in conflict with Taman Siswa principles. The murni group was also unwilling to view events within Taman Siswa in the framework of party politics. To them, the organization was above all such factionalism. According to Taman Siswa principles, the organization was open to all, irrespective of their religious or ideological commitments, and the murni members were therefore prepared to accept the communists within the organization.

A second factor was probably the PKI's increasing acceptance at the level of national politics. Sukarno's open patronage of the PKI probably divided the noncommunists in the Taman Siswa as to what stand they should take. There were those who, while opposed to the communists, were at the same time loyal supporters of the president. Many, too, were not sure if in fact some sympathizers of the pro-PKI faction were not simply pro-Sukarno. As a result, the strong anticommunists such as Tauchid and Tachir were not willing to risk a crisis on the issue at this stage and a possible split in the organization.

Around 1960 the conflict between the pro-PKI group and the noncommunists intensified and grew into an open and sometimes bitter struggle as each side sought to achieve control of the organization. The quiet and polite maneuvering that had characterized the preceding years gave way to hostility and public denunciations, each side accusing

${ }^{40}$ Ibid., p. 72. 
the other of deviations from Taman Siswa's original principles.41 Two events promoted the widening rift between the two factions. First, Dewantoro, the founder of the movement, died in 1959 and with his death the strength of the moderate murni group was greatly reduced. For a long time Dewantoro's calming influence had provided balance and stability in the organization. There was no one else with the authority to play this role. Second, the Taman Siswa congress in which a new Majelis Luhur was to be elected was due to be held in March 1960 . Noncommunist leaders in the Majelis Luhur saw this congress as a critical period. Although noncommunists still held an overwhelming majority in the Majelis Luhur, there were fears that the pro-PKI group would improve on its 1956 gains and, with better organization and the benefit of a possible bandwagon effect, essentially take over Taman Siswa. Particular causes for the concern among the noncommunists were the realization that they themselves lacked cohesion, and continual uncertainty as to where many "neutral" members would eventually stand.

In the face of a strong challenge from the pro-PKI faction, now encouraged especially by political developments in Jakarta, the Tauchid group decided to take measures of their own to retain control of the Majelis Luhur. The PKI letters and reports received by Tachir were skillfully used by the Tauchid faction to convince the murni group of the dangers of a complete PKI takeover. The Tauchid faction argued that the dispute was not over whether Taman Siswa members should be allowed close affiliations with particular political groups. What was at issue, they maintained, was a carefully prepared communist plan, with the object of penetrating the organization and taking it over completely. Should this happen, the communists would destroy that principle of free political association which the murni group was defending.

What followed was a series of shrewd and carefully organized attempts by Tauchid and his supporters to isolate the procommunists. These moves were led by Sutarto, who was entrusted with alerting branch leaders to the PKI threat and mobilizing the support of branches believed to be opposed to the communists. Others involved in the campaign were Tachir, Suprapto, Hanif D.K., and Sugondo. Tachir was to get support from the East Java branches, Suprapto was to look after Central Java, Hanif was to cover South Sumatra, and Sugondo North and West Sumatra. Tauchid and several others with known political affiliations kept a low profile, although they were active behind the scenes.42 The immediate objective of the offensive was to organize the votes of the noncommunist branches in the coming congress in a manner that would preclude a repetition of what had happened at the 1956 Majelis Luhur election. It was estimated that if the noncommunists were mobilized, the pro-PKI group, even with its known organizational skills, could not be expected to win more than two seats in the Majelis Luhur. What immediately concerned the Tauchid group was not so much the elimination of the pro-PKI faction, which they realized was not possible under the circumstances, but the prevention of any communist gains.

The moves of the Tauchid group proved temporarily successful. In the elections of the seventh congress, the pro-PKI faction managed to ke-V."

41"Rapat Panitia ke-VIII, 12 Nopember 1962," in "Notulen Rapat Madjelis Luhur

${ }^{42}$ Interview with Mohd. Tauchid, Jogjakarta, August 14, 1971. 
get only three seats, a net loss of four.43 The results must have surprised the radicals, who had been expected to do well. But the 1960 congress really only marked the beginning of an ever more open struggle between the pro-PKI faction and the noncommunists. The Tauchid counteroffensive broadened the conflict and more of the ordinary members were now aware of a deep division in the organization. Pro-PKI members now decided that a cautious and subtle approach was of little use.

Although the pro-PKI group had lost seats in the Majelis Luhur, its overal1 influence remained largely unaffected in Jogjakarta and the regions. It benefited from the banning of the PSI in 1960, a development which discredited many of the strongly anti-PKI members of the Majelis Luhur, including Tauchid and Sajoga. (Mohd. Said, although a nonparty man, was always considered a PSI sympathizer.)

Its influence in the branches could even be said to have increased. The PPTS was controlled by the pro-PKI faction, and the Taman Guru was staffed largely by those associated with the radicals. The Gading branch was also dominated by the pro-PKI faction, most of whom were also with the PPTS. The procommunist faction was also strong in the Ibu Pawiyatan. Only the Djetis branch in Jogjakarta remained solidly behind the Tauchid group. It was estimated eventually that half the branches in outlying areas in Central Java were dominated by procommunists, and that the proportion of pro-PKI branches in East Java was similarly high.

\section{Conclusion}

Thus, by the time of the events of October 1965, Taman Siswa had become highly politicized and deeply divided. The issues in the dispute became increasingly and inextricably tied to Jakarta politics. In this respect the radicals had succeeded. In July 1963, the Majelis Luhur, which had become badly split, was dissolved and replaced by a Dewan Pimpinan Eksekutip (Executive Leadership Council). Its formation was decided on not by the Taman Siswa in Jogjakarta but by several leading political figures, including Sartono and Sultan Hamengku Buwono. The composition of the new council was to be such as to reflect the prevailing political groupings in the country. The PKI gained a place in the five-man council with the appointment of Wikana.

By and large, the sorts of developments that took place in Taman Siswa also occurred elsewhere during the latter part of Guided Democracy. What happened in Taman Siswa ought therefore to be seen in the larger perspective of the general contest between the PKI and its enemies in the Indonesian politics of the period. The Education Ministry itself was divided along similar lines. The large teachers' union, the PGRI, split in two in July 1964.

But the controversy in Taman Siswa was also clearly related to the efforts by groups within the organization to search for a more effective and meaningful role in postwar Indonesia. In the context of a rapidly developing state educational system there were many who felt that Taman Siswa ought to adjust to changing educational needs and demands. The early fifties saw some attempts in that direction as Taman

43"Laporan Madjelis Luhur Taman Siswa," pp. 12-13. 
Siswa agreed to accept subsidies from the government and to bring their schools in 1 ine with those of the Education Ministry. But despite these changes, Taman Siswa schools continued to compare very poorly with the state schools and most private institutions. Furthermore, the Taman Siswa leaders' relationship with the Education Ministry remained distant. Many younger members came to believe and argue that fundamental and far-reaching reforms ought to be adopted. The increasing involvement of the PKI in educational issues and the growing identification of the Education Ministry with some of its initiatives provided these people with the occasion and the support to challenge the older leadership and at times the very premises of Taman Siswa. 


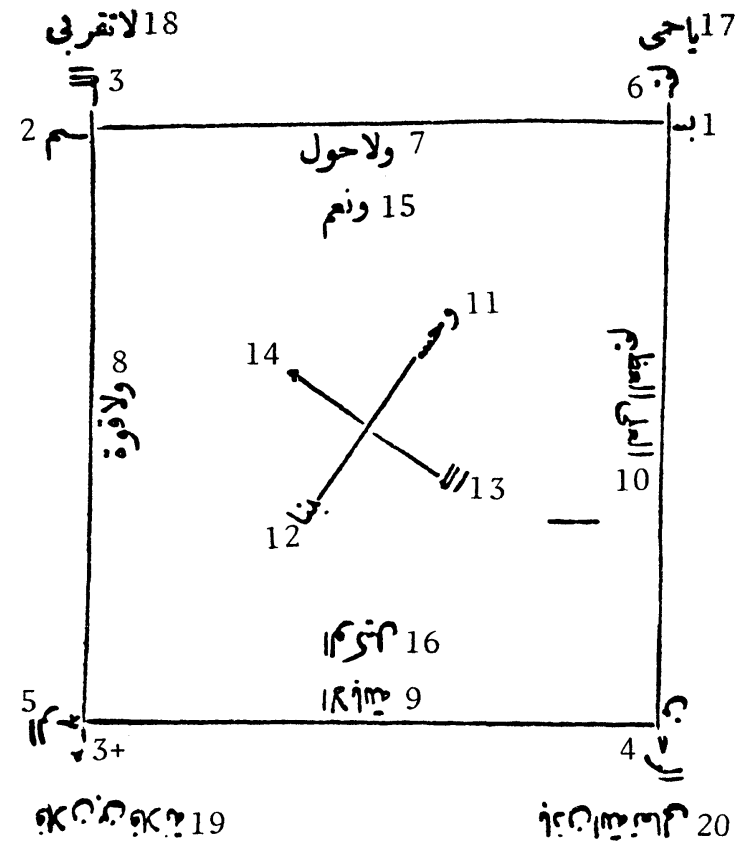

Amulet against fever, worn tied to the body.

Source: J. Kreemer, Atjêh (Leiden: Bril1, 1923), 2, p. 591.

The following transliterations and translations were made by George El'Hage. Numbers are provided for the reader's reference only.
1. Bis
11. Wahas
2. $\mathrm{mi}$
12. buna
3. al1a
13. Alla
$3+$. h
14. $\mathrm{h}$
4. arahman
15. Wanihma
5. a1rah
6. im
16. Alwakil
7. Wal ahaula
17. Hema
8. Wal aquata
18. 1a taqrubi
9. illa billah
19. fulan bin fulana
10. al ali al azim
20. Bismiallah taala

1-6. In the name of Allah the Merciful the Compassionate

7-10. There is no strength except by God the Great the Sublime

11-16. Our dependence is on God the Best the Protector

17-20. Fever, you will not approach anyone son of anyone (fem.), by God's will. 